(C) The Author(s), 2021. Published by Cambridge University Press on behalf of The Hegel Society of Great Britain. This is an Open Access article, distributed under the terms of the Creative Commons Attribution licence (https://creativecommons.org/licenses/by/4.0/), which permits unrestricted re-use, distribution, and reproduction in any medium, provided the original work is properly cited.

\title{
Bettina von Arnim's Romantic Philosophy in Die Günderode
}

\author{
Alison Stone
}

\begin{abstract}
This article puts forward a philosophical interpretation of Bettina von Arnim's epistolary book Die Günderode, in the following stages. First I situate von Arnim's work in relation to women's participation in early German Romanticism and idealism. The ideal of Symphilosophie, which was integral to Romantic epistemology, created possibilities for women to participate in philosophical discussion, albeit not on equal terms with men. This suggested that perhaps Symphilosophie between women could be more equal and reciprocal. However, interpreters have considered the Sym-in Günderrode and von Arnim's Symphilosophie more than the -philosophie, whereas here I foreground Die Günderode's rich philosophical content. I trace the stages in the unfolding dialogue between Günderrode and von Arnim and identify von Arnim's philosophical standpoint as it emerges from this dialogue. For Günderrode, finite beings are attracted together and can only fully unite by dying and superseding their boundaries. This feeds into a gigantic cosmic process through which the earth spiritualizes itself, progressively transcending its own materiality. Von Arnim likewise thinks that all finite beings are dynamically interconnected within the earth's creative process. But, unlike Günderrode, von Arnim thinks that finite beings can realize their interconnectedness within life without needing to die, which means in turn that material nature can rise into successive levels of spirit without its materiality having to be superseded. This metaphysical difference orchestrates many other philosophical disagreements between the two women. I then conclude that on balance, and with significant qualifications, Die Günderode embodies a successful Symphilosophie between women, but that von Arnim is simultaneously pointing out the fragility of Symphilosophie. The more independence dialogue partners have, the more liable they are to move away in new directions and abandon or outgrow the conversation, just as Günderrode turns away from von Arnim by the end of the book.
\end{abstract}

\section{Introduction}

In this article I put forward a philosophical interpretation of Bettina von Arnim's epistolary book Die Günderode (1840). ${ }^{1}$ The book recounts the story of the real-life 


\section{Alison Stone}

dialogue between von Arnim and her close friend Karoline von Günderrode in the 1800 s, using letters and writings that they exchanged at the time. ${ }^{2}$ Through this dialogue von Arnim articulates her philosophical standpoint in response to Günderrode's. For Günderrode, finite beings are attracted together and can only fully unite by dying and superseding their boundaries. This feeds into a cosmic process through which the earth spiritualizes itself, progressively transcending its own materiality. Von Arnim likewise thinks that all finite beings are dynamically interconnected within the earth's creative process. But, unlike Günderrode, von Arnim thinks that finite beings can realize their interconnectedness within life without needing to die, which in turn means that material nature can rise into successive levels of spirit while remaining material. This metaphysical disagreement orchestrates the two women's disagreements about many other philosophical topics.

Previously, scholars have mainly interpreted Die Günderode in relation to the Early German Romantic ideal of Symphilosophie-i.e. that one can best philosophize in conversations and written exchanges with others with whom one has living, emotional relationships. Because Early German Romanticism thus placed intellectual importance on emotional relationships, in a context where women were associated with personal relationships and emotions, Symphilosophie created openings for women to participate in philosophical discussion. Yet the male Romantics still saw women's role in these discussions as that of facilitating men's emotional and intellectual growth. Perhaps, then, Symphilosophie could escape these patriarchal distortions and become more genuinely inclusive if it occurred between women rather than between women and men. In this light, several interpreters have argued that Die Günderode embodies an equal, reciprocal and successful Symphilosophie between women - successful, that is, because both participants were women.

Thus, interpreters have considered the Sym- in Günderrode and von Arnim's Symphilosophie more than the -philosopbie - the relationship more than the philosophical conversations that animate it. ${ }^{3}$ Here I foreground instead Die Günderode's rich philosophical content, which deserves to be examined more than it has, including for the comparisons it enables us to make between Günderrode's and von Arnim's philosophical outlooks. Moreover, part of von Arnim's outlook is a distinctive conception of Symphilosophie. In discussions with Günderode, Bettine presses a Romantic critique of narrow intellectual systembuilding, urging that theorizing should remain rooted in our sensibility and emotional life. Günderode is portrayed by contrast as being unable to escape the lure of idealist theorizing, which eventually leads Günderode to withdraw from the friendship. By depicting this withdrawal, von Arnim highlights the fragility of Symphilosophie. That is: ideally, intellectual conversations should take place between equal participants who are each independent persons in their own right. Yet the more independence dialogue partners have, the more they are liable to move away in new directions and abandon or outgrow the conversation. When a dialogue 
is more equal and so more successful, it becomes more vulnerable to ending and transience. Ultimately, for von Arnim, this reflects the nature of life, which is always in dynamic growth, moving ever onwards.

I present these claims in the following stages. In Section II I explain how Symphilosophie was integral to Romantic epistemology and opened up possibilities for women to participate in philosophical discussion, albeit not on equal terms with men. Against this background, in Section III I explain the basic form and philosophical project of Die Günderode, trace the stages in the unfolding dialogue between Günderode and Bettine, and identify Bettine's/von Arnim's philosophical standpoint as it emerges from this dialogue. In Section IV I consider whether Die Günderode embodies a successful Symphilosophie between women. I conclude that on balance, and with significant qualifications, it does, but that von Arnim is simultaneously pointing out the fragility of Symphilosophie.

\section{Women and Romantic Symphilosophie}

Die Günderode came out in 1840, after the end of Early, Middle and Late Romanticism. But the conversations narrated in Die Günderode go back to the 1800s and the climate of Heidelberg Romanticism, which continued and took over some strands of Jena Romanticism. Moreover, in its form and content Die Günderode is faithful to many central ideas of Jena Romanticism-not only the ideal of Symphilosophie but also the mingling of philosophy and literature, knowledge as a dynamic work-in-progress, the epistemic importance of feeling and relationships, and nature as an organic whole. So in this section I explain the context of Early German Romanticism, Symphilosophie, and their relations to women, because this is necessary for appreciating what von Arnim does in Die Günderode.

Women were integral to Jena Romanticism. Caroline Schlegel-Schelling and Dorothea Veit-Schlegel were core members of the Jena Romantic circle alongside Friedrich and August Schlegel, Novalis, Ludwig Tieck, Schleiermacher and Schelling. A copious letter-writer, Schlegel-Schelling also penned numerous essays and reviews, mostly published under the name of her then husband August Schlegel. Behind the scenes, she collaborated with him on the German translation of Shakespeare's dramatic works that is known as the 'Schlegel-Tieck' edition. Tieck continued the project after Schlegel and Schlegel-Schelling's interest in it had lapsed, although Tieck assigned the lion's share of the translating to his daughter Dorothea along with Wolf Heinrich Graf von Baudissin. The 'Schlegel-Tieck' translation, then - a monumental achievement of Early German Romanticismowes much to women. ${ }^{4}$

Ludwig Tieck's sister Sophie Tieck-Bernhardi was also close to the Jena circle; amongst her writings, the essay 'Lebensansicht' ('AView of Life', 1800) appeared in 


\section{Alison Stone}

the third issue of the Athenaeum, the short-lived (1798-1800) journal edited by the Schlegel brothers as the mouthpiece of Jena Romanticism. Sophie Schubart-Mereau was another woman who had links to the circle; she attended Fichte's 1794 seminar, published in Schiller's journal Die Horen-which regularly featured Romantic contributions-and married another Jena associate, Clemens Brentano. Brentano then became key to the Heidelberg Romantic circle, along with Achim von Arnim, with whom he compiled the collection of German folk poems and songs Des Knaben Wunderhorn (1805-08). Women were again integral to the Heidelberg circle: besides Schubart-Mereau, Bettina von Arnim, née Brentano, was linked with Heidelberg Romanticism through her older brother Clemens; through Achim von Arnim, whom she married; and through her close friend Günderrode, who was in turn the lover and interlocutor of yet another Heidelberg Romantic, the philologist G. F. Creuzer.

These women not only took part in the real-life discussions out of which Romantic philosophy precipitated and helped to maintain the social networks in which these discussions happened; they also wrote novels, stories, essays, translations, plays, letters and other writings that creatively span genre boundaries. Some of these women had a more literary focus, as with Schlegel-Schelling and Veit-Schlegel, while others leaned more overtly towards philosophy. Günderrode's writings included notes, drafts, and sketches of a systematic metaphysics and philosophy of nature, and von Arnim worked out her philosophy of life in response in Die Günderode.

Women were thus heavily involved in developing Romantic ideas and forms of expression. Yet these women have not received the same level of attention as their male counterparts. Considerable scholarship on Romantic women exists in literary, historical and German studies, ${ }^{5}$ but philosophers have been slow to recognize that Romantic women produced some explicitly philosophical work, that their literary work addresses philosophical themes, and that women contributed to articulating Romantic philosophy. ${ }^{6}$ Compared to the men, Romantic women's work has been viewed more exclusively through a 'literary' prism. This reflects the long-standing contrast between 'feminine' writing and 'masculine' philosophizing, already well entrenched at the time of Early German Romanticism. This contrast was one factor that prevented women from engaging in the Romantic conversation on an equal footing with men. Even so, by the standards of the time, women's level of inclusion in Romanticism is impressive.

This inclusion arose from Romanticism's central intellectual commitments, above all its ideal of Symphilosophie. As Friedrich Schlegel put it:

Perhaps a whole new epoch of science and art would be inaugurated were symphilosophy and sympoetry to become so common and deeply felt that there would be nothing odd were 


\section{Bettina von Arnim's Romantic Philosophy}

several people of mutually complementary natures to create works in communion with each other. $(A F: \# 125)^{7}$

Symphilosophie was connected with Romantic epistemology. In partial reaction against Fichte's idealist project of constructing a complete system of knowledge, the Romantics maintained that this could only ever be a system-in-progress. We must aspire to completeness of knowledge but cannot expect to reach it. Rather, the work of systematizing our knowledge must remain ongoing, as we strive to integrate the elements and branches of our knowledge, ranging them under ever larger syntheses and identifying parallels between hitherto separated fields. The more completely our knowledge is systematized, the more all its parts will be reciprocally interconnected. ${ }^{8}$ This requires co-operation from many knowers.

Why cannot a single individual comprehensively synthesize the entirety of the state of knowledge, as Hegel would attempt? For the Romantics, this is impossible because any given individual has a merely limited, partial perspective on reality. Reality as a whole - the interconnected universe- exceeds the grasp of any single person, as it exceeds any single proposition, hypothesis, theory or discipline. ${ }^{10}$ Individuals can learn to appreciate the limitations of their perspectives and then seek to enlarge them. But individuals cannot do this purely through internal selfreflection, for then they will remain trapped in their own finitude. ${ }^{11}$ Confronting one's limitations requires, first, the felt encounter with the real world outside the self, and, second, the promptings of other individuals bringing their distinct perspectives. ${ }^{12}$ Here the Romantics oppose Fichte's early project of systematizing knowledge based on the absolute I or self-consciousness: this leaves the self trapped in its own confines. A true system of knowledge requires the collection and integration of the perspectives of distinct individuals, as many of them as possible_-including women.

The case for including women in the epistemic endeavour was reinforced by the Romantic commitment to the epistemic importance of sensibility. For the Romantics, intuition and feeling precede thought (see, e.g., AF: \#412). The intuition that reality is an absolute (unlimited) whole motivates us to try to know about it in ever-expanding syntheses. Yet conceptually organized knowledge continues to fall short of what we intuitively feel to be unlimited. This discrepancy between intuition and discursive knowledge makes us aware that the latter is limited, driving us to keep expanding our knowledge endlessly. ${ }^{13}$ Thus the felt apprehension that the world is infinite supplies a 'check' or Anstoß on the self and its discursive cognition. ${ }^{14}$

This emphasis on the epistemic role of feeling created a favourable climate towards women because they were associated with feeling and sensibility. We see this in many Romantic fairy tales, in which romantic love for women re-awakens men to the importance of feeling, breaking them out of a narrow preoccupation 


\section{Alison Stone}

with theoretical system-building. ${ }^{15}$ Novalis's fairy tale of Hyacinth and Rose-blossom, within The Novices at Sais, is emblematic. Hyacinth abandons his childhood sweetheart Rose-blossom to travel the world seeking insight into the mysteries of the universe. At last nearing his goal, he lifts the veil of Isis to discover none other than Rose-blossom. Put non-poetically, the futile effort to complete our knowledge will lead us on, endlessly, restlessly, until love intrudes and pulls us back to the prior realm of feeling in which satisfaction can be reached — as it cannot in the realm of theory.

Sophie Tieck-Bernhardi's fairy-tale 'The Old Man in the Cave' makes the same point ([1800] 2001). The protagonist Leonhard visits an old magician who lives alone in a cave. Leonhard requests the gift of 'knowing everything in its innermost and outermost essence, and particularly everything within one's own self', and 'the gift of seeing my own thoughts standing before me after I have crafted them' (2001: 78). A typical Fichtean idealist, Leonhard wants to know everything starting from his knowledge of himself. The magician grants his request-but the gift is not what Leonhard hoped for. He now finds himself constantly surrounded and bothered by a group of unpleasant and confusing figures who embody his thoughts. Because most of his thoughts are nascent, half-formed, confused, and unclear, so are the misshapen figures who hound him at every step. Fortunately he meets and falls in love with a mysterious girl, who turns out to be the old magician's estranged daughter. Leonhard thereby brings about the father and daughter's reconciliation, and in gratitude the magician frees Leonhard from the curse of his thoughts. He advises Leonhard that 'a person does not really achieve anything through too great introspection, except great confusion' (2001: 87). Happily united with his beloved, Leonhard realizes that love is, indeed, more important than complete knowledge. Like other Romantics, Tieck-Bernhardi is objecting that the idealist project is doomed. Pursuing it will leave us lost in theory, estranged from the real, sensible world, just as Leonhard finds his paths forward obstructed by the menacing thought-figures that he escapes only by reconnecting with feeling and affect through the magician's daughter.

Romantic views on Symphilosophie and sensibility were interdependent. The reason why one can only expand one's knowledge through interaction with others is that these others provide a real, external, and felt 'check' upon the self, exposing its take on the world as partial and limited. For the Romantics, we need constantly to make an ironic movement, reflecting on our limitations. But we cannot make this movement without others to alert us to where our limitations lie. In response we refine our perspectives; but then further conversations with others alert us to new limitations, and so on ad infinitum. Only through dialogue with others can we progressively enlarge our conceptions of the world.

In Novalis's and Tieck-Bernhardi's fairy tales women are the objects of men's love, returning men to affective life out of obsessive theorizing. But the idea of 


\section{Bettina von Arnim's Romantic Philosophy}

Symphilosophie implies that ideally relationships between men and women should be intellectual as well as affective. For then these relationships will not only remind men of the priority of feeling but also enable women to 'check' men's perspectives, advancing the growth of knowledge. Moreover, our intellectual conversations with others will be richest when they are embedded in affective relationships: the more we feel for someone, the more forcibly will their perspectives check us and the more motivated we will be to enlarge our own perspectives in response. In these ways Romantic epistemology implied that women must be admitted into the intellectual conversation.

Symphilosophie was linked with Sympoesie, the Romantic project of mixing philosophy and literature, because the complete system of knowledge for which we are endlessly striving cannot exist in one form, discipline, or genre alone, but must unite them all —otherwise it will not match the infinitude of the world and our range of perspectives on it. Sympoesie again created openings for women because they were associated with literature as well as sensibility and the emotions. Upper-class women were expected to read and discuss literature as part of their social role as guardians of taste and educators of the next generation. To be sure, women authoring books was still contested-hence Günderrode published her two poetry collections under the gender-neutral pseudonym 'Tian', and Dorothea Veit-Schlegel's novel Florentin (1801) appeared anonymously but with Friedrich Schlegel named as 'editor'. Nonetheless, compared to philosophy, literature was relatively hospitable to women-letter-writing most of all, for writing and circulating letters was also part of the upper-class woman's social role. Von Arnim drew on this when she created the innovative genre of the epistolary book.

Unfortunately the openings that Romanticism created for women came with limitations. In the two Romantic fairy tales mentioned earlier, the female characters remind the male protagonists of the importance of feeling. That is, here women are useful for men. Friedrich Schlegel's novel Lucinde has the same structure: the protagonist Julius has moved through relationships with successive women, each fulfilling different facets of his personality, until he finally reaches complete fulfilment with Lucinde, who satisfies him intellectually, spiritually, imaginatively, emotionally and corporeally. The novel perfectly illustrates the tendency for intellectual relationships with women to be valued for what they bring to men. To be fair, Schlegel condemned women's subordination (see Valpione 2020: sec. 2). Yet, like other male Romantics, he still tended to value women's equality for its potential intellectual and emotional benefits to men, as we see in Lucinde.

Moreover, this model of women facilitating men's creativity was replicated in the real-life asymmetries in the intellectual collaborations between Romantic men and women. For example, Schlegel-Schelling's and Dorothea Tieck's translation work was silently incorporated under their husband's and father's names. Von Arnim experienced this herself: she helped to collect the material for Des Knaben 


\section{Alison Stone}

Wunderhorn but its authorship was attributed only to Achim von Arnim and Clemens Brentano. She came to feel that while Clemens encouraged her philosophical and literary interests, ultimately he wanted her 'to be his muse, the reflection of his own personality. [...] She [knew] that despite their close bonds, Clemens [could] neither accept nor understand her true character' (Shafi 1995: 102-3). As she wrote to him: 'If you had grasped me in my own language, then you would not like me for a moment, $[\ldots]$ the talk would have been of other things. A swarm of misunderstandings' (WB: 1: 199).

These problems did not mean that Symphilosophie had to be rejected altogether, for it had positive features. But women needed a way to realize the positives without the damaging gender asymmetries. This created momentum towards a Symphilosophie between women, which held out the possibility of a genuinely symmetrical conversation.

\section{Von Arnim's Romantic philosophy in Die Günderode}

Against this background of women's imperfect inclusion in philosophical Romanticism, von Arnim and Günderrode engaged in dialogue from 1804-06. Drawing on her recollection of their dialogue decades later, and using letters and other written materials from the 1800s, von Arnim put together Die Günderode, 'the first printed exchange of letters between two young women writers' in German (Metzger 2000). It is also a work of philosophy. To be sure, it is not a systematic treatise; but then von Arnim practises and advocates a different type of philosophy which mingles with life, sensibility and personal experience. The book is not a conventional treatise precisely because it is a work of Romantic philosophy, adhering to the Romantic views in epistemology looked at in Section II.

Before going into Die Günderode we should acquaint ourselves with the reallife persons who provide its dramatis personae: Karoline von Günderrode and Bettina von Arnim herself. Günderrode's (1780-1806) life-story is tragic. From an aristocratic but impoverished family, she lived from 1799 onwards in a conventstyle residence where she was able to read voraciously, both in German idealism and Romanticism and across literature, the sciences, mythology and comparative religion (see Martinson 2005). She experimented with writing across forms and genres that blended philosophy and literature, bringing out two collections of poetic and prose fragments, Poems and Fantasies (1804) and Poetic Fragments (1805). A romance with the legal theorist Friedrich Karl von Savigny ended in disappointment when he married von Arnim's sister Kunigunde. Günderrode then fell in love with Creuzer, who was already married, but having intended to divorce his wife to be with Günderrode he got cold feet and ended the affair. Already given to depression, and struggling to combine being a woman and a philosopher-poet, 
Günderrode was overcome with despair and committed suicide. Adding insult to injury, Creuzer then withdrew her last poetry collection Melete from publication, seeking to avoid any further association with her. Fortunately von Arnim kept Günderrode's memory alive, enabling later generations to rediscover Günderrode's thought and work.

Born Bettina Brentano, von Arnim (1785-1859) was convent-educated after her mother's death, until her father also died and she came under the care and tutelage of her grandmother, the renowned woman of letters Sophie von la Roche, who amongst other things edited the literary journal Autumn Days (in which Günderrode published her 'Story of a Brahmin'). Von la Roche hosted a salon, through which von Arnim came to meet Goethe, (Ludwig) Tieck, and various Romantic co-workers of her brother Clemens, including her future husband Achim von Arnim. She undertook extensive reading and studying, supervised by Clemens and Günderrode. However, once she and Achim were married they had seven children, and so her next two decades were largely consumed with domestic responsibilities. After Achim died in 1831, von Arnim resumed her literary and philosophical activity, publishing a trilogy of epistolary books: Goethe's Correspondence with a Child (1835), Die Günderode (1840) and Clemens Brentano's Spring Wreath (1844). All were based on original correspondence and other documents from the hey-day of German Romanticism, but von Arnim heavily revised and reshaped the epistolary materials, developing a unique literary-cum-philosophical form. She too kept a salon, and in the 1840s turned her attention to social and political matters, supporting the Young Germany movement, meeting Karl and Jenny Marx, and writing several political works. Right through the 1830s and 1840s, then, von Arnim remained faithful to the original impetus of Early German Romanticism-including its political radicalismlong after the other Romantics had either died or moved on and become more conservative. $^{16}$

Von Arnim is similarly faithful to Early German Romantic philosophical concerns in Die Günderode. This is reflected in the book's construction from her correspondence with Günderrode, letters exchanged with other people, diary entries, poems, and drafts of dramatic works and essays. ${ }^{17}$ This construction reflects the Romantic position that we must gather and integrate many perspectives, genres and forms to approximate the world's richness and complexity. Die Günderode, then, is not merely a historical record of factual conversations. It is 'a new kind of composition that goes beyond the documentary and elaborates a philosophical discourse that owes [...] much to Plato' (Köhler 2004), especially the Platonic dialogues.

Indeed, Bettine calls herself 'Dion' to Günderode's 'Plato', saying that 'we two philosophers [...] hold great and deep speculations' (WB: 1: 245). The original Dion was one of Plato's disciples; thus, Bettine wishes to learn from Günderode 


\section{Alison Stone}

about philosophy. Conversely Günderode wishes she had more of Bettine's spirit of life: 'genius always makes air and light for itself, it always exists ethereally [...] In such things you are a born genius, in this I can only be your pupil, and strive after you with great diligence' (WB: 1:310). Von Arnim had long adopted the persona of a child of nature, and she reprises this in Die Günderode. As she portrays her younger self, Bettine cannot help but approach philosophical themes, ideas, and systems in terms of whether or not they enable her vital growth. Philosophy must serve life, not lure us away from the sensory world. ${ }^{18}$ Meanwhile, Günderode struggles to keep life in charge of philosophy, and ultimately succumbs to the domination of idealism and is drawn away from life. As Margaret Fuller put it, Bettine and Günderode respectively personify 'Nature and Ideal' (Fuller 1842: ix). This difference overarches their debates about history, heroic action, poetic creativity, nature, knowledge, language and music. These debates unfold as follows.

At first Günderode is Bettine's mentor and teacher, urging Bettine to discipline her reading, learning, studying and even her life and possessions. Bettine feels scattered and dispersed: across various fleeting ideas, her own and other people's, and the events of her busy social schedule; endlessly distracted from studying by the variety and vitality of nature around her. Her letters juxtapose talk of social encounters, repeatedly condemning their philistinism and the deadening artificiality of social mores and customs, with rich descriptions of nature, especially plant life-gardens, forests, trees, flowers (a contrast that will shape Bettine's philosophical standpoint). ${ }^{19}$ Günderode reiterates the importance of studying things systematically and ordering one's thoughts into a whole. Bettine resists, complaining 'your Schelling and your Fichte and your Kant are wholly impossible men to me' (WB: 1: 307). In reply Günderode sends a poetic fragment in which the character Narcissus says that natural life and love have no permanence (WB: 1: 326-29). Earlier she had sent a fragment in which a teacher declared that we can make spiritual connections with others that can survive temporal change and physical death, arguing that these cross-temporal connections between minds make possible our knowledge of past historical agents and events (WB: 1: 301-5). Günderode therefore urges Bettine to settle to disciplined study of the past under her history tutor. Modelling the orderliness she advocates, Günderode's tone is dignified, grand, collected-coming from the heights, Bettine complains: 'You want to remain untouched [...] Even now you still believe that somewhere there is a height where the air blows so pure [...]' (WB: 1: 383).

Struggling with her history lessons, Bettine rails that the dead facts of history are meaningless compared to living, present nature (WB: 1: 396-97). No, Günderode replies, we need to understand how the ancient peoples created civilizations, cultures, and religions out of nowhere if we are to originate anything truly new ourselves: 'Active and forceful in every undertaking $[. .$.$] they lead us to a con-$ cept of what the human soul could be if it grew further and further in simple 
service to itself' (WB: 1: 401). Bettine disagrees: if we neglect the living present for the sake of the 'history-wasteland' (WB: 1: 405), then no action in the present will be possible (WB: 1: 406). Moreover, she adds, all the history she is studying concerns war and destruction, the cutting down of life (WB: 1: 407-8). This is no model for those who want to live. Günderode protests that Bettine is misrepresenting her position (WB: 1: 414). But Bettine continues to object to her studies and to any attempt to impose order on her ideas:

I cannot write a book [...] I would have to make a herbarium of my thoughts and dry them so that they could be laid next to one another; meanwhile so many flowers would fade, and I don't want that. [...] The abyss of rotten history beneath me, the unreachable starry heavens above me-and at night thoughts that break my head. (WB: 1: 425-27)

Bettine is reluctant to render all her thoughts into conscious knowledge. She draws a parallel with music: the intervals between notes give music its power to affect us (WB: 1: 398-99). In Günderrode's fragment 'The Realm of Tones', she took a different view: music arises when an external impact (e.g., striking a piano key) releases the spiritual elements that were trapped in separate tones, elements that are now set free to unite into harmonies. ${ }^{20}$ So Bettine and Günder(r)ode are in dispute here. Music's power derives for Günderrode from the confluence of tones, for Bettine from the intervals between tones. The implication, for Bettine, is that what is unsaid, unknown, incipient, yields meaning. Meaning emerges when we let what is unknown germinate in darkness, like a seed coming to fruition under the ground, or dreams forming out of the restfulness of sleep, or the imagination taking wing at night. (Eschewing regular hours, Bettine routinely stays up long into the night- the creative time.) Faced with these protests from Bettine, Günderode finally consents to Bettine abandoning her historical studies, conceding that imposing order and systematicity is clearly not right for her (WB: 1: 435).

The next phase in the dialogue is prompted by Bettine's reading of Hölderlin (WB: 1: 430). ${ }^{21}$ She comes to a new realization about her philosophical standpoint, pressing it on Günderode and elaborating it in successive letters. One acts authentically, Bettine now maintains, when one acts from one's own nature:

And as the elements in undisturbed action produce, carry, feed and complete life, likewise in the enjoyment of an undisturbed development an element again prepares itself in which an ideal of the spirit can blossom, thrive and complete itself. [...] $[T]$ he spirit flows in sensation [Empfindung], and it emerges from everything that nature produces [...] (WB: 1: 442) 


\section{Alison Stone}

By heeding one's own nature one can withstand and defy stultifying conventions (Sittenleben; WB: 1: 444). One's own nature, though, is not self-contained but a manifestation and ramification of outer nature: the self is a confluence of natural forces. Consequently, one can be true to one's own nature only by being true to outer nature. This makes creative action possible because nature is the original creative force, suffused with dynamic and electric currents. By letting nature flow through us, its currents course into us, we can act and think creatively - and produce poetry, in which we present the flow of natural forces in a procession of images (WB: 1: 446-47).

This takes Bettine to her proposal for a 'hovering-religion' (Schwebe-Religion) whose 'fundamental law' (Grundgesety) is to be that 'the human being should always perform the greatest actions and no others' (WB: 1: 449). Great deeds (größe Handlungen) are ones in which we create something genuinely new that goes beyond existing conventions (so the 'hovering' is between new ideals and existing reality; the 'religion' consists in adherence to an ideal). But to perform great deeds, we need to act from our own nature. Accordingly, another 'chief principle of our hovering-religion is to institute no education [Bildung] — that is, no trained beings' (WB: 1: 468) (contrary to what Günderode had urged on Bettine). Great deeds must needs go against training and education, for the latter are customary and artificial, impeding nature's vital flows. Just as nature is endlessly productive, growing into ever new forms, so we must never be afraid to defy convention and must keep performing new actions that, by changing the world, make more new actions possible. 'Every action must have the highest goal, and a higher goal is directly the seed of the future' (WB: 1: 533): a great action creates something new, which enables more truly new actions, and so on.

Günderode's replies begin to be briefer from this point onwards because, she explains, she is oppressed by 'heartache' (WB: $1: 497)$. She remains very affectionate towards Bettine, glad to hear of her experiences and ideas, and feeling warmed by Bettine's vitality and energy. Now although Günderode does not say this herself, Bettine's view of living nature is a response to Günderrode's view of it, of which Bettine knew through their conversations. Günderrode stated this view in several places, above all her essay 'The Idea of the Earth' (which remained unpublished during her lifetime). On this view, all finite beings are separated parts of an original whole that has generated them. Because these beings are part of the whole, they are all drawn to unite- through gravity, magnetism, chemistry, electricity and life ( $S W$ : 1: 446; this is the 'law of attraction', Gesetz der Anziehung; SW: 1: 359). The same process applies at the spiritual level, where like-minded beings are drawn together. But beings can only fully unite by ceasing to exist as finite entities at all, that is, by dying or being destroyed. This 'law of mortality' reigns throughout nature (Gesetz. der Sterblichkeit, SW: 1: 359). On dying, beings return into the whole, which Günderrode identifies with the earth. But because these finite beings were 
pervaded by vital currents or 'elements' ( $S W: 1: 446)$ before they dissolved, they bring these elements back into the earth, strengthening it (SW: 1: 359-60). This causes it to regenerate new finite beings that are more vitalized and spiritual. As this cycle is repeated many times over, the entire earth is progressing towards an ultimate state in which everything will be spiritual.

Clearly Günderrode's position influenced Bettine's view that nature is the ultimate creative power and is pervaded by dynamic currents that flow through everything and draw separate beings together: 'the whole of nature speaks to me, which means it kisses my soul, the soul must grow through this, it is the soul's element, for everything that has life has its element in nature' (WB: 1: 528). But there are also differences between the two women's views. For Günderrode, the elements within separate beings pull them beyond their finite embodiment, towards a reunion with and into the whole that can be accomplished only in death. Through the earth's subsequent rebirthing of more and more spiritualized entities, eventually the whole earth will become spiritual and all material limitations will be superseded. For Bettine, too, finite beings strive to unite with each other beyond their boundaries and limits-but they can reach this unity by becoming interconnected and communicating as the material beings that they are. 'See this is true spirit, it was not thought but was the original life-spirit [...] I live only when my spirit stands in reciprocal action with nature' (WB: 1: 529; my emphasis). Natural bodies can unite and vitalize one another within life. The earth develops into successive layers of spiritual interconnectedness and complexity, but those layers remain within material nature rather than having to leave materiality behind or transfigure it.

This metaphysical difference has significant consequences. Where Günderrode sees a 'law of mortality', Bettine sees more of a law of vitality, encapsulated in her 'hovering-religion', according to which we must act from nature and realize nature's creativity in our poetry, thinking and deeds. For Bettine, if we live in harmony with nature, and let its vital currents flow through us, then we can accomplish great deeds. We can reach beyond our limits, and beyond artificial social limits, just as nature's powers reach beyond the separation between its parts. Thus we can act autonomously within our finite embodied lives. We need not await fulfilment through subsequent lives but can achieve fulfilment, and bring nature's powers to fulfilment, in the here and now.

Now sunk deep in melancholy, Günderode rather sadly replies that she writes poetry not as a form of heroic action but to compensate for her lack of action and timidity: 'If I cannot be heroically brave, and am always ill from hesitating and hesitating, at least I will fill my soul with their heroism' (i.e. that of the Spartan women she is reading about) (WB: 1: 535). Indeed, near the end of the dialogue she will suggest that theirs is not a heroic age. No longer does anyone do anything truly great, inspired by an idea; rather, everyone is driven by petty ambition and narrow 


\section{Alison Stone}

self-interest—as with Napoleon (WB: 1: 728). Only in the past do we encounter genuine greatness, hence the importance of transcending the existing world in thought and connecting with these past eras. So, Günderode reiterates, one must train one's mind to transcend the present with its ephemeral comings-and-goings, and grasp the eternal ideas which form our bridge to the minds of great actors of the past (WB: 1: 727-28).

In response Bettine enlarges on points she had already made:

[We can do] better than suppress our instinct under the alien power of old prejudices [...] The higher nature can only produce itself from itself, for the powerful drive to development within us is exactly why we need to develop [...], therefore: let the inner spirit prevail, and nothing alien (WB: 1: 616)

Again, to let our nature flow and express itself poetically we must remain keyed into the vital flows of outer nature (WB: 1: 619-20)—and other people. For whereas the human body is organized like an animal, the spirit is organized like a plant, and grows through contact and attraction with other souls (WB: 1: 678).

Furthermore, Bettine insists, there are great individuals amongst us, even now. It is merely customs that lead us to deny and misrecognize the great souls around us who act from nature and are the spiritual aristocrats. Instead, we only recognize those who by convention and artifice are aristocrats (WB: 1: 698). Pace Günderode, Bettine insists that here she is not defending tyrants; she always sides with the oppressed (Unterdrïckten; WB: 1: 636). ${ }^{22} \mathrm{It}$ is the truly great individuals she is celebrating, not those whom society falsely elevates to honour.

By now we are in the final part of the dialogue. Having gained confidence in her own convictions, Bettine expounds them in more and more of a monologue, while Günderode's replies become increasingly short, distant, and sporadic. Bettine reiterates that it is by acting from nature that we achieve autonomy or 'self-being' ('bandlen ist Selbstsein', WB: 1: 662)—action from oneself, not from obedience to others ('thinking for oneself [Selbstdenken] is the highest courage', WB: 1: 662). Spirit is the body's development, and only when a body thrives, by being in concert with nature and participating in its currents (WB: 1: 675), can that body grow into mind and ideas: 'all thinking is to the spirit what budding and growing are in nature' (WB: 1: 655). As part of thinking with and from nature, we must follow nature's moral and social laws (WB: 1: 621). In nature there is a reciprocal mingling of elements; likewise, society should implement equal rights for all groups, including Jews and all Christian denominations (WB: 1: 618).

We can never reach complete knowledge, Bettine continues. Our goal is instead to be knowing (Wissendsein), to desire knowledge and to expand the soul's life (WB: 1: 626): 
The highest goal that any truth can attain is to dissolve itself in a higher truth [...] to negate itself.-The spirit should never take itself for the highest, but must hold higher those who affect it, for they challenge it-develop it. (WB: 1: 719)

This is Bettine's formulation of the Romantic idea of infinite approximation: that we must keep striving for the truth without ever reaching it, and that we can only maintain this striving through dialogue with others who challenge us. Indeed, Bettine repeatedly writes that she can only think in response to Günderode, not alone:

For intuitions [Ahnungen] to become truths in the sight of spirit, to gain actual existence, the spirit must first mix itself with another spirit-with its genius-intuition realises the genius in us. (WB: 1: 633)

Yet Günderode is growing distant; Bettine worries that Günderode is leaving her (WB: 1: 659-60). Günderode says that she must follow a difficult road and leaves the path of happiness to Bettine. Why, Bettine asks, will Günderode not let them share happiness together? (WB: 1: 660) Günderode rather coldly notes how different their moods are (WB: 1: 683). Bettine wishes to stay connected: 'All life that is in contact with you depends on you; you no longer have a separate life; - and actual life is an overflowing into everything, which cannot be stopped' (WB: 1: 699). Günderode answers that Bettine must go her own way now, and that the two women's paths are diverging. Their metaphysical outlooks differ: 'Mind enhances [steigern] this world; it is through mind alone that actual life is alive; [...] everything else is passing shadows' (WB: 1: 728). For Günderode, mind gives meaning to the world, and only by being idealized in this way does the world become alive. In contrast, for Bettine, mind can only idealize things in the first place because it arises from vital currents flowing through and into our bodies and ascending into more spiritual guise. Whereas Günderode stresses that life depends on mind, Bettine stresses that mind depends on life.

The narrative does not continue up to Günderrode's suicide but ends after she withdraws from the friendship. Yet Günderrode's suicide is prefigured in several ways. First, it is acknowledged in displaced form in Bettine's final letter describing her reconciliation to the death of her admired older teacher, the Jew Ephraim (a spiritual aristocrat in her eyes). Second, from the start of the dialogue, Bettine fears that Günderode is drawn beyond the world, towards death, and cannot be happy with the two women's individual relationship within life (e.g., WB: 1: 316). In the end these fears will be realized. Third, Bettine closes the book with Günderrode's poem 'The Frank in Egypt'. The Frank's unsatisfiable longing has driven him to Egypt, to fight in wars, and pursue long scientific inquiries, but 


\section{Alison Stone}

now he has realized that love is most important: 'love must beckon to the tired pilgrim $[\ldots]$ Love has found its way out of chaos', he declares in the book's closing line (WB: 1: 746). The point, perhaps, is that before Günderode turned away from Bettine she was able to reach these insights into the importance of love. Unfortunately, Günderode has now fallen back into the same compulsive longing for a super-sensory world from which the Frank suffered. With our knowledge of Günderode's suicide-to-come hovering in the background, the narrative conveys that Bettine has failed to entice Günderode back from idealism into emotional life, with a result that will be fatal. ${ }^{23}$

\section{The fragility of Symphilosophie}

I have presented the dialogue between Die Günderode's protagonists and shown how von Arnim's philosophical standpoint emerges through this dialogue. On this basis we can reconstruct her distinctive conception of Symphilosophie.

In many ways the dialogue shows Symphilosophie in action, as Bettine and Günderode maintain a conversation in which philosophical, literary and personal concerns mingle indissolubly. They exchange ideas and feelings at once, with the ideas growing out of the feelings, and their responses overlapping and interweaving. Their letters both state philosophical views and are literary texts—a realization of Sympoesie. Von Arnim embraces the Romantic view that theorizing should be rooted in feeling and be done in open and dynamic processes in which dialogue partners exchange and revise ideas without closing their thoughts into a final system.

Plausibly, these features of the ideal Romantic dialogue could be realized because the dialogue was between two women and not compromised by gendered asymmetries. Understandably, then, Die Günderode's interpreters have often seen this work as embodying a successful Symphilosophie between women. For Edith Waldstein (1992), the book is a utopian and successful experiment at creating a genuinely symmetrical philosophical relationship. Whereas von Arnim's attempted dialogue with Goethe was painfully one-sided, here we have true equality and reciprocity because the dialogue is between women. As Waldstein says of all von Arnim's epistolary books, she 'never pretends to be the sole source of that which she produces, but always emphasizes in both form and content that dialogue and communication are essential' (1992: 96). But Die Günderode is unique 'because the epistolary partners are on an equal footing' (1992: 105), resulting in 'co-operation, mutual respect and reciprocal enrichment' (1992: 112). ${ }^{24}$ Becker-Cantarino agrees that von Arnim 'articulated [...] in Die Günderode an egalitarian, subject-strengthening conception of friendship' (2019: 161-62). Renata Fuchs (2016) likewise views the dialogue broadly positively, as a relationship in 
which two distinct individuals emerge and express themselves in their particularity, although Fuchs concedes that the dialogue becomes increasingly monologic as Günderode recedes.

However, this concession points us towards several respects in which the dialogue in Die Günderode is not straightforwardly equal and symmetrical. First, there is the book's formal construction. Although Günderode's letters and writings are integral to the book- which von Arnim could not have written alone-nevertheless we see Günderode through von Arnim's eyes. Von Arnim has revised the epistolary material and other writings and organized them into a narrative. So, while Günderrode talks back to Bettine, 'checking' her partial perspective, these 'checks' are themselves mediated through von Arnim's editorial hand. ${ }^{25}$ To be fair, von Arnim signals this by calling Günderrode Günderode and herself Bettine, not Bettina: this reveals the gap between Bettina von Arnim as editor and Bettine the character, and between Günderode as character and the real Günderrode.

Second, Bettine develops her philosophical standpoint across the book, comes out from under Günderode's intellectual shadow, tests her views against Günderode and ultimately has to go her own way. This suggests that Die Günderode is a Bildungsroman in which the one undergoing the Bildung is Bettine, who eventually becomes independent of Günderode. Günderode would then be facilitating Bettine's self-realization, playing the same role as the female beloved in many Romantic narratives: enabling the protagonist to assume their creative subjectivity.

Third, this suggests that Die Günderode may not be so different from von Arnim's Goethe-book after all. The latter sparked controversy because in it von Arnim not only portrayed her younger self as 'Goethe's number-one fan', ${ }^{26}$ but also exaggerated Goethe's interest in her, falsifying the historical record. Thus the book was criticized for containing factual inaccuracies, and for recasting other people and past events in the light of von Arnim's wishful imagination. Von Arnim was accused of being 'Romantic' in the bad sense: inflating her own subjectivity, portraying the world as if it were as she fantasized it to be, and using others to augment her own self. ${ }^{27}$ However, Die Günderode offers a much more fully realized dialogue arising from a more mutual relationship and a friendship that was real and deep. But it is still not entirely mutual. Its amorousness is largely on Bettine's side, and she admits to using Günderode as her 'echo' and sending her 'floods of words' (WB: 1: 624). Arguably, too, she portrays Günderode largely as a foil to her own self-with Günderode drawn to death and not life, idealism and not materiality, systematicity and not thinking-in-process, order and not flux, theory and not perception, etc.

Fourth, as we have seen, von Arnim portrays Günderode as being drawn inexorably towards death. This myth of Günderrode as a death-bound obsessive 


\section{Alison Stone}

has had undue and detrimental influence on her reception. Günderrode scholars have especially criticized von Arnim for fostering this myth (see, e.g., Ezekiel 2016: 4, Raisbeck n.d.), protesting that von Arnim has not accurately represented Günderrode in her own right.

All these considerations notwithstanding, on balance Die Günderode remains a dialogue between two independent voices. We saw earlier how Romantic narratives typically treat women as love-objects who restore men to the realm of feeling, facilitating men's creative projects. In Die Günderode, instead, the female beloved (Günderode) is loved by another woman (Bettine); moreover, Günderode stands not for feeling but for theoreticism. Accordingly Günderode does not restore Bettine to feeling, but attempts to pull her towards theory, mind and spirit. It is Bettine who holds the role Romantic narratives usually accord to the beloved woman - that of restoring the would-be idealist to nature, life and feeling. In this case, though, Bettine does not succeed.

This reveals several further respects in which Die Günderode is a genuine dialogue. Here the beloved woman — the person who remains connected with life and the emotions, namely Bettine - is not an object within the story but its primary narrator, a subject who has her own perspective on the relationship with Günderode and tells us about it. This reverses the normal Romantic narrative structure so that both parties speak, the theory-driven idealist and the emotional lover of everyday life. Additionally, Die Günderode is a genuine dialogue precisely because Bettine fails to keep her friend close. For in a relationship of two who are really other to one another, each is liable to go their own way, even against the other's wishes. This risk is unavoidable in relationships where both parties are agents in their own right. The very fact that the women's relationship breaks down shows that they are both independent agents.

Here von Arnim shows us something important about Symphilosophie. When intellectual conversations take place within living relationships, these relationships and conversations may always end. Unlike in Romantic fairy tales, no happy ending is guaranteed. Thus just when Symphilosophie is realized as a truly mutual and reciprocal dialogue between two-because it is between women, in this case-the dialogue thereby incurs new risks. In the end these risks derive from the processual and mutable character of life and nature as von Arnim conceives them. A living, organic relationship arises where its participants are open to nature's dynamic forces and flows, borne along on these currents and exchanging ideas and experiences in a vital process. But just because the participants are open to flowing nature, they are liable to be drawn away from one another along nature's volatile currents. The more vital a dialogue is-and the better it realizes the ideal of Symphilosophie - the more mutable and fragile it will be.

Von Arnim's conception of Symphilosophie, then, is bound up with her view of life. That view is not simply opposed to Günderrode's but responds creatively to it- 
so that, again, there is a genuine dialogue between the two women's views. For Günderrode, all finite life obeys the 'law of mortality': each life is destined to end as living beings seek to reunite with one another, merge into the greater whole, and then undergo rebirth in new more spiritual guises. For von Arnim, material life indeed rises into endless developments and refinements, but these developments do not pass beyond but occur within natural life. Yet despite von Arnim's relative optimism about life, her relationship with Günderode ends. By implication, material life is finite after all, subject to breaks and endings as well as developments and positive transformations. Nature is not only creative but also suffused with mortality. Von Arnim has taken Günderrode's emphasis on mortality and reconciled it with her own more optimistic emphasis on the potentials of this-worldly life. Bettine's and Günderode's different outlooks and preoccupations have come to a reconciliation.

\section{Alison Stone \\ Lancaster University, UK \\ a.stone@1ancaster.ac.uk}

\section{Notes}

${ }^{1}$ I agree with Loreley French that von Arnim's works are better called epistolary books than epistolary novels (French 1996: 213), as they are not conventional works of fiction.

2 I use 'von Arnim' rather than 'Brentano-von Arnim' for simplicity. Within Die Günderode von Arnim calls herself 'Bettine' and Günderrode 'Günderode'. I do the same when discussing the two women as presented in Die Günderode, otherwise I speak of 'von Arnim' and 'Günderrode', although this distinction becomes fuzzy at times.

${ }^{3}$ On Die Günderode and female friendship, see e.g., Becker-Cantorino (2019) and Waldstein (1988, 1992), and on how it realizes Symphilosophie, see Fuchs (2016). Stone (2014), however, compares von Arnim's view of nature in Die Günderode to Schelling's philosophy of nature.

${ }^{4}$ On women's role in the 'Schlegel-Tieck' translation, see Stone and Valpione (2021 forthcoming).

5 See, e.g., Blackwell and Zantop (1990), Daley (1998), Frederikson and Goodman (1995), Goodman and Waldstein (1992).

${ }^{6}$ This is changing, however: see, e.g., Cahen-Maurel and Valpione (2020), Ezekiel (2016).

7 Abbreviations:

$A F=$ Friedrich Schlegel, Athenaeum Fragments [1798], in F. Schlegel, Philosophical Fragments, trans. P. Firchow (Minneapolis: University of Minnesota Press, 1991)/ Athenäums-Fragmente, in Kritische Friedrich Schlegel Ausgabe vol. 2, ed. E. Behler, et al., (35 vols. Paderborn: Schöningh, 1958-). Cited by fragment number.

FS = Novalis, Fichte Studies, trans. J. Kneller (Cambridge: Cambridge University Press, 2003)/ Philosophische Studien der Jahre 1795/96 (Fichte-Studien), in Novalis Schriften vol. 2, 


\section{Alison Stone}

ed. P. Kluckhohn and R. Samuel (6 vols. Stuttgart: Kohlhammer, 1960). Cited by fragment number.

$W B=$ Bettine von Arnim, Werke und Briefe in drei Bänden, ed. W. Schmitz and S. von Steinsdorff (3 vols. Frankfurt: Deutscher Klassiker, 1986). Cited by volume and page number.

$S W=$ Karoline von Günderrode, Sämtliche Werke und ausgewählte Studien, ed. W. Morgenthaler (3 vols. Basel: Stroemfeld/Roter Stern, 1991). Cited by volume and page number.

${ }^{8}$ For more on Romantic epistemology, see Stone (2011).

${ }^{9}$ For the contrast between the Romantic emphasis on the limits of knowledge and the Hegelian aspiration to total knowledge, see Frank (2004: 24).

${ }^{10}$ Novalis: 'The essence of identity [of the whole] can only be presented in an illusory [partial] proposition' (FS: \#1).

11 'Has not Fichte too arbitrarily packed everything into the I? [...] Can an I posit itself as I, without another [...] Not-I [...] The act by which the I posits itself as I must be connected with the antithesis of an independent Not-I and of the relationship to a sphere that encompasses them' (FS: \#5-7).

12 'Human beings feel the boundary that circumscribes everything for them' (FS: \#3; my emphasis). The epistemic importance of both feeling, and other individuals, is stressed by von Arnim (e.g., WB: 1: 633, 719).

13 'Reflection finds the need of philosophy [...] because the need is in feeling' (FS: \#19).

14 The idea of the check or Ansto $\beta$ comes from Fichte, although in his 1794 Wissenschaftslebre he saw the check as resulting from an external world that is posited by the self in the first place. Afterwards he changed his mind and came to see the check as coming from an independent outer world, a view the Romantics endorsed. See Zöller (2000).

15 The fairy tale was a genre that the Romantics reinvented, reflecting their fascination with magic and enchantment.

16 The Early German Romantics 'developed a concept of community to counter [...] atomism and anomie $[\ldots]$; they formulated an ethic of love and self-realization [...] and they championed many modern social values, such as the emancipation of women, sexual freedom and the right of divorce' (Beiser 1995: xii-xiii). On von Arnim's loyalty to these Early German Romantic themes, see Wolf (1995).

${ }^{17}$ On the components of Die Günderode, see Schmitz (1986: 1102-12) and Oehlke (1905)—who, however, popularized the misleading description of von Arnim's epistolary books as 'novels' (Briefromane).

${ }^{18}$ For example, Bettine says: 'Isn't the spirit of creative nature [Schöpfernatur] more powerful than the philosopher with his triangle-when he pushes the creative force within himself here and there, what does he want?' (WB: 1: 308). But contrary to Günderode who then refers to Bettine's 'dislike of philosophy' (WB: 1: 311), Bettine is not opposing philosophy altogether. Rather her view is that: 'Wisdom must be natural; [...] The man of spirit must love nature above all, with true love, then he blooms, - then nature plants spirit in him' (WB: 1: 307-8). 


\section{Bettina von Arnim's Romantic Philosophy}

${ }^{19}$ For von Arnim the plant is a model of nature, creativity, writing and autonomy. Her dialogue with Günderode evolves in a branching, twining, arborescent pattern rather than a linear one, and both women celebrate and revere plants, especially trees (e.g., WB: 1: 582-83).

20 This reflects Günderrode's metaphysics and belief in the 'law of attraction' (see below). For 'The Realm of Tones', see Günderrode (1920-22: vol. 3: 69-70).

21 The phases I am identifying in the dialogue are distinct from the two parts into which von Arnim divided Die Günderode. Self-reflexively, the first part ends (WB: 1: 546-49) just after Bettine has written to Günderode about Hölderlin's conception of the poetic caesura or interruption. For Hölderlin, the caesura can come from a break in a narrative, 'empty words' in a poem, or a dramatic transition, like the arrival of the blind prophet Teiresias within Oedipus the King (Hölderlin [c.1803] 2003: 195-96). A caesura is anything that pauses the flow of events and in doing so heralds an ending to come-as Teiresias's arrival foreshadows Oedipus's descent into doom. The division within Die Günderode, then, heralds Günderode's future departure from Bettine, even though the two remain very close at the time; but once we are into part two, Günderode's melancholy will settle in and she will gradually recede.

${ }^{22}$ Despite Günderrode's interest in great founding figures of the past, she believed that such individuals tended to act tyrannically and crush others underfoot. This is a theme in her plays, which often deal with great historical actors-Attila the Hun, Muhammad, and others that she invented; see Günderrode (2016).

23 This fits in with von Arnim's 1808 'Report on Günderrode's Suicide', later included in her Goethe-book (von Arnim [1835] 1959). In it she portrayed Günderrode as other-worldly and longing for death, yearning to escape the material world into the spiritual one. For a while this infects Bettine, who starts to feel so ethereal that she imagines she can fly, becoming quite unwell. She recovers and reconnects with life; not so Günderode. Poignant as von Arnim's report is, Ezekiel objects, with some justice, that it initiates the long tradition of regarding Günderrode as obsessed with death (see Ezekiel 2016).

${ }^{24}$ For a longer elaboration, see Waldstein (1988). Another similarly positive view is that of Growe (2003: 156).

25 Indeed, Catherine Grimm concludes that: 'A considerable amount of what the Karoline-figure says or writes was written by von Arnim which makes the work the product of one mind rather than a collaborative effort. It must therefore be seen as von Arnim's own poetic construction' (Grimm 2008: 3-4). (I think this is too strong, however.)

26 As Mary McAlpin puts it (2005), taking the phrase from Stephen King's Misery.

${ }^{27}$ On von Arnim's reception, see Goozé (1995). Beginning with the American Transcendentalist Margaret Fuller in 1842, von Arnim's defenders replied that she complicates divisions between object and subject, reality and imagination. (Fuller translated part of Die Günderode into English (von Arnim 1842); the translation was later completed by Minna Wesselhoeft (von Arnim 1861). Both translations are now rather archaic, so although I have consulted them translations from Die Günderode are my own.) 


\section{Alison Stone}

\section{Bibliography}

Arnim, B. von. [1835] (1959), Goethes Briefwechsel mit einem Kind. Bettina von Arnim: Werke und Briefe, ed. G. Konrad, vol. 2. Köln: Bartmann.

Arnim, B. von. [1835] (1990), 'Report on Günderode's Suicide', trans. von Arnim, in J. Blackwell and S. Zantop (eds.), Bitter Healing: German Women Writers 1700 1830. Lincoln NB: University of Nebraska Press.

Arnim, B. von. (1842), Günderode, partial trans. M. Fuller. Boston: Peabody.

Arnim, B. von. (1861), Correspondence of Fräulein Günderode and Bettine von Arnim, trans. M. Wesselhoeft. Boston: Burnham.

Becker-Cantarino, B. (ed.) (2019), Bettina von Arnim Handbuch. Berlin: de Gruyter. Beiser, F. (1995), 'Introduction' to The Early Political Writings of the German Romantics. Cambridge: Cambridge University Press.

Blackwell, J. and Zantop, S. (eds.) (1990), Bitter Healing: German Women Writers 1700-1830. Lincoln NE: University of Nebraska Press.

Cahen-Maurel, L. and Valpione, G. (eds.) (2020), Symphilosophie 2: The Women Writers of Philosophical Romanticism. URL: https://symphilosophie.com/symphilosophie-22020-eng/

Daley, M. (1998), Women of Letters: A Study in the Personal Writing of Caroline Schlegel-Schelling, Rahel Varnhagen, and Bettina von Arnim. Columbia SC: Camden House.

Ezekiel, A. (2016), 'Introduction: The Work of Karoline von Günderrode', in K. von Günderrode, Poetic Fragments, trans. A. C. Ezekiel. Albany: State University of New York Press.

Frank, M. (2004), The Philosophical Foundations of Early German Romanticism, trans. Elizabeth Millán-Zaibert. Albany NY: State University of New York Press.

Frederikson, E. P. and Goodman, K. R. (eds.) (1995), Bettina Brentano-von Arnim: Gender and Politics. Detroit: Wayne State University Press.

French, L. (1996), German Women as Letter Writers, 1750-1850. Madison: Fairleigh Dickinson University Press.

Fuchs, R. (2016), “I Drink Love to get Strong”: Bettina Brentano von Arnim's Romantic Philosophy and Dialogue in Die Günderode, Women in German Yearbook 32:1: 1-24.

Fuller, M. (1842), 'Preface' to von Arnim, Günderode, trans. M. Fuller. Boston: Peabody.

Goodman, K. R. and E. Waldstein. (eds.) (1992), In the Shadow of Olympus: German Women Writers Around 1800. Albany NY: State University of New York Press. Goozé, M. (1995), 'The Reception of Bettina Brentano-von Arnim as Author and Historical Figure', in E. P. Frederikson and K. R. Goodman (eds.), Bettina Brentanovon Arnim: Gender and Politics. Detroit: Wayne State University Press. 
Grimm, C. (2008), “Die Seele sehnte sich hinaus in den Schnee”: The Meaning and Function of Outside Space in Bettine von Arnim's Die Günderode, The Sophie Journal 1: 1-14.

Growe, U. (2003), Das Briefleben Bettine von Arnims_-Vom Musenruf zur Selbstreflexion. Würzburg: Königshausen \& Neumann.

Günderrode, K. von. (1920-22), Gesammelte Werke, ed. L. Hirschberg. 3 vols. Berlin: Goldschmidt-Gabrielli.

Günderrode, K. von. (2016), Poetic Fragments, trans. A. C. Ezekiel. Albany: State University of New York Press.

Hölderlin, F. [1803] (2003), 'Remarks on “Oedipus", in J. Bernstein (ed.), Classic and Romantic German Aesthetics. Cambridge: Cambridge University Press.

Köhler, A. (2004), 'Arnim, Bettina von, 1785-1859', in C. J. Murray (ed.), Encyclopedia of the Romantic Era, 1760-1850. London: Taylor \& Francis.

Martinson, S. D. (2005), “... aus dem Schiffbruch des irdischen Lebens”: The Literature of Karoline von Günderrode and Early German Romantic and Idealist Philosophy', German Studies Review 28:2: 303-26.

McAlpin, M. (2005), 'Goethe's Number-One Fan: A Neo-Feminist Reading of Bettina Brentano-von Arnim', Comparative Literature 57:4: 294-311.

Metzger, E. A. (2000), 'Karoline Friederike Louise Maximiliane von Günderrode 1780-1806', in M. Konzett (ed.), Encyclopedia of German Literature. Chicago: Fitzroy Dearborn.

Oehlke, W. (1905), Bettine von Arnims Briefromane. Berlin: Mayer \& Müller. Raisbeck, J. (n.d.) 'Günderrode'. www.germanlit.org. URL: https://sites.google. $\mathrm{com} /$ site/germanliterature/18th-century/guenderrode

Schmitz, W. (1986), 'Kommentar' to Bettine von Arnim Werke und Briefe, vol. 1. Frankfurt: Deutscher Klassiker.

Shafi, M. (1995), 'The Myth of Psyche as Developmental Paradigm in Bettina Brentano-von Arnim's Epistolary Novels', in E. P. Frederikson and K. R. Goodman (eds.), Bettina Brentano-von Arnim: Gender and Politics. Detroit: Wayne State University Press.

Stone, A. (2011), 'The Romantic Absolute', British Journal for the History of Philosophy 19:3: 497-517.

Stone, A. and Valpione, G. (2021 forthcoming), 'Idealism and Romanticism', in K. Gjesdal and D. Nassar (eds.), The Oxford Handbook of Nineteenth-Century Women Philosophers in the German Tradition. Oxford: Oxford University Press.

Stone, L. S. (2014), 'Beilage zum Brief: On "Epistolarity" and Materiality in Bettine von Arnim's "Die Günderode”, Colloquia Germanica 47:3: 287-305.

Tieck-Bernhardi, S. [1800] (2001), 'The Old Man in the Cave', in J. Blackwell and S. C. Jarvis (eds.), The Queen's Mirror: Fairy Tales by German Women, 1780-1900. Lincoln NE: University of Nebraska Press. 


\section{Alison Stone}

Valpione, G. (2020), 'Expanding the Canon: The Political Philosophy of Bettina von Arnim', Symphilosophie 2: 123-56.

Waldstein, E. (1988), Bettina von Arnim and the Politics of Romantic Conversation. Columbia SC: Camden House.

Waldstein, E. (1992), 'Goethe and Beyond: Bettine von Arnim's Correspondence with a Child and Günderode', in K. R. Goodman and E. Waldstein (eds.), In the Shadow of Olympus: German Women Writers Around 1800. Albany NY: State University of New York Press.

Wolf, C. (1995), 'Your Next Life Begins Today: A Letter about Bettine', in E. P. Frederikson and K. R. Goodman (eds.), Bettina Brentano-von Arnim: Gender and Politics. Detroit: Wayne State University Press.

Zöller, G. (2000), 'German Realism: The Self-Limitation of Idealist Thinking in Fichte, Schelling and Schopenhauer', in K. Ameriks (ed.), The Cambridge Companion to German Idealism. Cambridge: Cambridge University Press. 